\title{
Statistical ICharacteristics For Identification Defect of Solar Panel with Naive Bayes
}

\author{
NWiliani ${ }^{1,2}$, T K A Rahman' ${ }^{2}$, S Ramli ${ }^{3}$ dan A Sani ${ }^{2,4}$ \\ ${ }^{1}$ ICT Departement, National Institut of Science Technology, Jakarta, Indonesia \\ ${ }^{2}$ ICT Departement, Asia e University, Kuala Lumpur, Malaysia \\ ${ }^{3}$ Computer Science Departement, University Pertahanan Nasional Malaysia, Malaysia \\ ${ }^{4}$ Information System Departement, STMIK Widuri, Jakarta, Indonesia
}

E-mail: ninukwiliani@istn.ac.id

\begin{abstract}
Energy that comes from the sun is energy without limits and never runs out. This energy is alternative energy that can be converted into electrical energy, namely by using solar cells. But people who live in remote areas will have difficulty getting electricity. Solar panels are an alternative power source. Solar panels are an alternative way to produce electricity. The production of good solar panels is an important thing that must be done to produce the desired electrical energy. The uncontrolled production process causes various types of defects that appear in solar panels. This study applies the Bayes theorem to classify data by estimating the probability that tuple $\mathrm{X}$ is in a class. Using thirty samples consisting of fifteen images of undamaged solar panels and fifteen images. The level of accuracy of image processing for identification of flawed solar panel textures by the Naive Bayesian Classifier method or Simple Bayesian Classifier is around eighty three percent. The results of this study are expected to be used as a reference for the initial detection system of damage that occurs on the surface of the Solar Panel
\end{abstract}

Keywords: Energy, image processing, a defect of solar panel, Bayesian Classifier.

\section{Introduction}

Indonesia is one of the tropical countries and has uniform sunlight and can be captured throughout the Indonesia archipelago throughout the year. Therefore the sun is a potential energy source [1]. Energy is obtained from heat that propagates to the surface of the earth. The choice of renewable energy sources makes perfect sense because solar energy obtained from sunlight can reach 3x1024 Joules per year[2]. To get and process energy in the sun so that it can be used to fulfill daily needs, the Solar Panel is used. In the use of solar panels, of course there is care that must be done. Solar panels must be in good condition in order to produce the appropriate energy expected. damage that occurs after use arises on the surface of the solar panel. It is difficult to identify or detect some defects or damage properly because 
it could have happened in a hidden manner in the system so that it is difficult to identify until in the end the entire system is destroyed [3]. Recycling solar panels that are not used can cause environmental damage if not handled carefully because the materials used are silicon, selenium, cadmium, and sulfur hexafluoride (greenhouse gas) [4]. this will become a new problem in the environmental recycling process [5].

Fatalities can occur due to slow detection of damage. Several severe fire hazards have been reported due to late reporting of damage [6], the 2009 fire incident at California Bakersfield and also in 2011, there was a fire at a 1 MW PV power plant in Mount Holly Northern California. Several studies have been carried out with other methods using images of solar panels as data material [7]. Other research uses methods to detect cracks of solar panels by image processing, which contain gray transformations, contour detection, with Gauss-Laplacian transformation [8]. This study applies the Bayes theorem to classify data and make estimates to determine the probability that a tuple $\mathrm{X}$ is in a class. The method used is Naive Bayesian Classifier or Simple Bayesian Classifier. By using images surface photos that will be used as data sets to distinguish which images of damaged Solar Panels and Solar Panels are not damaged. The results of this study are expected to be used as a reference for the initial detection system of damage that occurs on the surface of the Solar Panel

\section{Method}

This study applies the Bayes theorem to classify data by estimating the probability that tuple $\mathrm{X}$ is in a class. Using thirty samples consisting of fifteen images of undamaged solar panels and fifteen images. The method used is Naive Bayesian Classifier or Simple Bayesian Classifier. The calculation technique used is Laplacian Correction or Laplace Estimator to avoid a probability of zero value.

\subsection{Texture of Image}

The texture is the spatial distribution of grayscale in the groups of pixels. Texture of image cannot identify for pixels. The surface have texture information; if the area enlarged without a scale, they have similar properties to the original surface[9]. Regular patterns appear with a certain distance and direction. The noncolored surface in the image can contain texture information if the surface has a certainpattern such as used wood surface, stone surface, sand beds, etc.

Texture analysis is commonly used as an intermediate process[10]. For performing image classification and interpretation, An image classification process based on texture analysis generally requires feature extraction which can consist of two types of methods: statistical methods and structural methods. Statistical methods use the calculation of the gray level disribution[11]. Statistic method use the calculation of the gray level distribution statistics by measuring the level of contrast and granularity[12]

\subsection{Statistic Feature Extraction}

The feature extraction method is retrieval based on the characteristics of the image histogram, that shows the probability of the occurrence of the value of the greyscale in an image[13]. The result of the histogram, several parameters can be calculated, including mean, variance, skewness, kurtosis and entropy.

The calculation curve of the characteristic parameters for the surface texture of the solar panel shown in figure 1 and 2. 


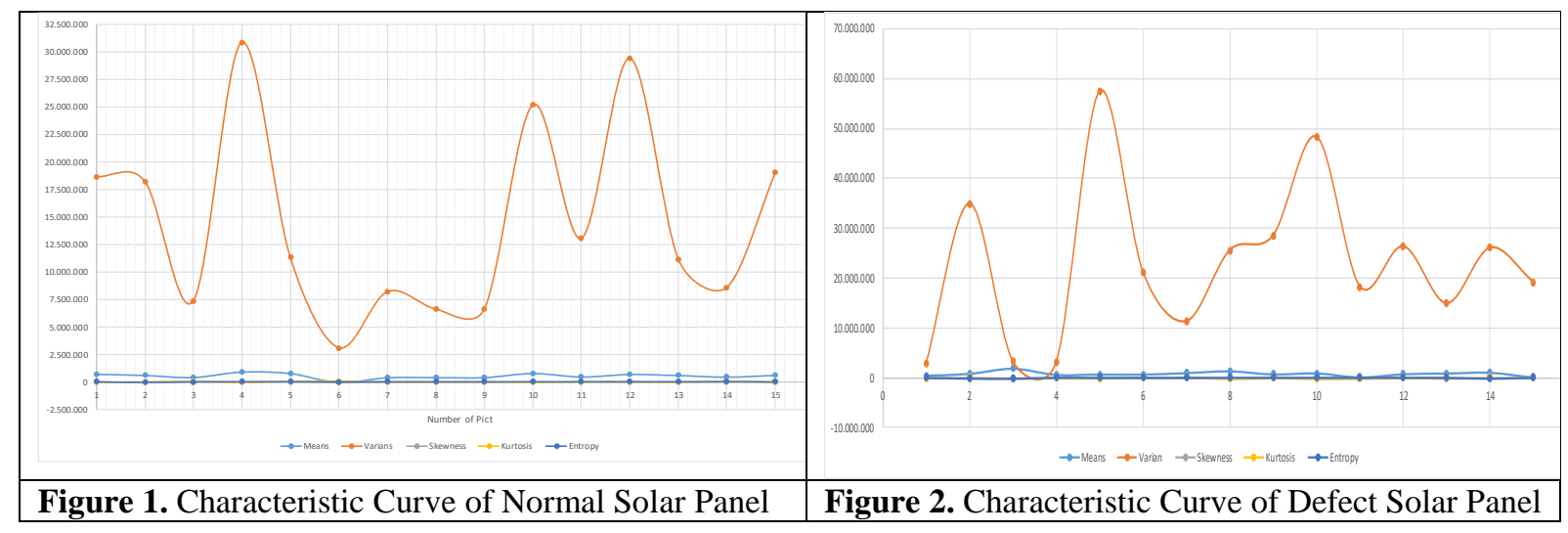

\section{Findings and Discussion}

This study will test 30 images with a *.jpg extension. From 30 image data, the value of the texture parameters will be determined namely mean, variance, skewness, kurtosis, and entropy. Where 15 sampleshavebeen taken on normal and abnormal solar panel surface texture. The solar panel image in jpg format is converted to grayscale and displayed on the grayscale histogram.

\subsection{Means}

Shown the size of dispersion of image.

$\mu=\sum_{n=0}^{N} f_{n .} P\left(f_{n}\right)$

Where,

Fn = Gray inteensity

$\mathrm{P}(\mathrm{fn})=$ Histogram Value

\subsection{Variance}

Shown variation elements on the histogram

$\delta^{2}=\sum_{n=0}^{N}\left(f_{n}-\mu\right)^{2} P\left(f_{n}\right)$

Where

Fn $\quad=$ Gray intensity

$\mu \quad=$ Means

$\mathrm{P}(\mathrm{fn}) \quad=$ Histogram Value

\subsection{Skewness}

Show the degree of inclination of the relative histogram curve of an image

$\alpha_{3}=\frac{1}{\delta^{3}} \sum_{n=0}^{N}\left(f_{n}-\mu\right)^{3} P\left(f_{n}\right)$

Where,

$\delta^{3}=$ Standard deviation of gray intensity value

Fn $\quad=$ Gray incensity

$\mu \quad=$ Means

$\mathrm{P}(\mathrm{fn}) \quad=$ Histogram Value

\subsection{Kurtosis}

Show the degree of inclination of the relative histogram curve of an image $\alpha_{4}=\frac{1}{\delta^{4}} \sum_{n=0}^{N}\left(f_{n}-\mu\right)^{4} P\left(f_{n}\right)-3$

Where

$\delta^{4} \quad=$ Standard deviation of gray intensity value

Fn $\quad=$ Gray incensity

$\mu \quad=$ Means

$\mathrm{P}(\mathrm{fn}) \quad=$ Histogram Value 


\subsection{Entropy}

Show the irregularities from of an image

$H=-\sum_{n=0}^{N} P\left(f_{n}\right)^{2} \log P\left(f_{n}\right)$

Where,

$\mathrm{P}(\mathrm{fn}) \quad=$ Histogram Value

3.6. Algorithm Naive Bayes

$P\left(C_{i} \mid X\right)=\frac{P\left(X \mid C_{i}\right) P\left(C_{i}\right)}{P(X)}$

Where,

$\mathrm{Ci}=$ Hypothesis data on the specific class

$\mathrm{X}=$ Unknown Data

$\mathrm{P}(\mathrm{CiIX})=$ Probabilistic Hypothesis $\mathrm{C}$ with $\mathrm{X}$

$\mathrm{P}(\mathrm{XICi})=$ Probabilistic Hypothesis $\mathrm{X}$ with $\mathrm{C}$

$\mathrm{P}(\mathrm{Ci})=$ Probabilistic Hypothesis $\mathrm{Ci}$

$\mathrm{P}(\mathrm{Ci})=$ Probabilistic Hypothesis Xi

The Data has a numerical value or Gaussian probability, with means and standard deviation on each class, with $g(X, \mu, \delta)=\frac{1}{\delta \sqrt{2 \pi}} e^{\frac{-(x-\mu)^{2}}{2\left(\delta^{2}\right)}}$

So we have,

$P\left(X_{k} \mid C_{i}\right)=g\left(X_{i}, \mu_{i}, \delta_{i}\right)$

Table 1.Data on Normal Sollar Panel.

\begin{tabular}{lllll}
\hline No & Means & Variants & Std & Medians \\
\hline 1 & 750.945 & $4,32 \mathrm{E}+03$ & $1,87 \mathrm{E}+07$ & 11.982 .025 \\
\hline 2 & 647.554 & 4.272 & $1,83 \mathrm{E}+07$ & 8.736 .300 \\
\hline 3 & 460.565 & 2.712 & $7,36 \mathrm{E}+06$ & 14.053 .050 \\
\hline 4 & 954.505 & 5.557 & $3,09 \mathrm{E}+07$ & 20400850 \\
\hline 5 & 822.386 & 3.368 & $1,13 \mathrm{E}+07$ & 15201825 \\
\hline 6 & 37.04 .00 & 1.765 & $3,12 \mathrm{E}+06$ & 6980200 \\
\hline 7 & 434.877 & 2.864 & $8,20 \mathrm{E}+06$ & 7876525 \\
\hline 8 & 447.736 & 2.576 & $6,63 \mathrm{E}+06$ & 7946225 \\
\hline 9 & 447.736 & 2.576 & $6,63 \mathrm{E}+06$ & 7946225 \\
\hline 10 & 826.157 & 5.021 & $2,52 \mathrm{E}+07$ & 8508500 \\
\hline 11 & 506.401 & 3.616 & $1,31 \mathrm{E}+07$ & 12698150 \\
\hline 12 & 740.621 & 5.425 & $2,94 \mathrm{E}+07$ & 16371000 \\
\hline 13 & 638.957 & 3.338 & $1,11 \mathrm{E}+07$ & 9577375 \\
\hline 14 & 492.538 & 2.933 & $8,60 \mathrm{E}+06$ & 7064350 \\
\hline 15 & 654.361 & 4.368 & $1,91 \mathrm{E}+07$ & 9559100 \\
\hline$\mu$ & 588.356 & 3.647 & 14.508 .812 & 10.993 .447 \\
\hline$\sigma$ & 230979,09 & 1136,169804 & 8704169,5 & 3995844,17 \\
\hline & & & &
\end{tabular}

Table 2. Data of Abnormal Solar Panel

\begin{tabular}{lllll}
\hline No & Means & Varians & Std & Medians \\
\hline 1 & 447799 & 1685,2291 & 2839997 & 2.103 .750 \\
\hline 2 & 813442 & 5908,0911 & 34905541 & 25.488 .950 \\
\hline 3 & 1844662 & 1799,6391 & 3238701 & 36.581 .025 \\
\hline 4 & 606235 & 1782,5053 & 3177325 & 7035450 \\
\hline 5 & 683362 & 7580,0838 & 57457671 & 12110375 \\
\hline 6 & 667174 & 4607,0568 & 21224972 & 11074650 \\
\hline 7 & 973785 & 3368,3281 & 11345634 & 16164025 \\
\hline 8 & 1320077 & 5058,5155 & 25588579 & 24325300 \\
\hline 9 & 699975 & 5344,6011 & 28564761 & 1065105216 \\
\hline 10 & 903512 & 6953,5287 & 48351562 & 16324250 \\
\hline 11 & 85824 & 4275,9325 & 18283599 & 17763725 \\
\hline 12 & 727542 & 5133,4107 & 26351905 & 14389248 \\
\hline 13 & 891236 & 3864,784 & 14936555 & 9448175 \\
\hline 14 & 1026914 & 5107,2076 & 26083569 & 14750050 \\
\hline 15 & 60643 & 4377,6952 & 19164215 & 17220575 \\
\hline$\mu$ & 783478,8 & 4456,4406 & 22767639 & 85992317,6 \\
\hline$\sigma$ & 441054,3 & 1765,0708 & 15721234 & 270988335 \\
\hline
\end{tabular}

The probability of Normal Solar Panel

$P(X i \mid$ Normal $)=\frac{1}{\delta \sqrt{2 \pi}} e^{\frac{-(x-\mu)^{2}}{2\left(\delta^{2}\right)}}$

If we hava some data (Abnormal11)

Means $\left(\mathrm{X}_{1}\right)=85824$

Std $\left(X_{2}\right)=4275,9325$

Varians $\left(\mathrm{X}_{3}\right)=18283599$ 
Medians $\left(\mathrm{X}_{4}\right)=17763725$

$P\left(X_{1} \mid\right.$ Normal $)=\frac{1}{230979,1 \sqrt{2(3,14)}} e^{\frac{-(85824-588,356)^{2}}{2\left(230979^{2}\right)}}=0,000115684$

$P\left(X_{2} \mid\right.$ Normal $)=\frac{1}{1136,1698 \sqrt{2(3,14)}} e^{\frac{-(4275-3,647)^{2}}{2\left(1136,1698^{2}\right)}}=0,002570263$

$P\left(X_{3} \mid\right.$ Normal $)=\frac{1}{8704169,5 \sqrt{2(3,14)}} e^{\frac{-(4275,93253-14508812)^{2}}{2\left(8704169,5^{2}\right)}}=1,15409 \mathrm{E}-06$

$P\left(X_{4} \mid\right.$ Normal $)=\frac{1}{3995844,17 \sqrt{2(3,14)}} e^{\frac{-(17763725-10993447)^{2}}{2\left(3995844,17^{2}\right)}}=2,6348 \mathrm{E}-06$

The probabilityof Abnormal Solar Panel

$P(X i \mid$ Unnormal $)=\frac{1}{\delta \sqrt{2 \pi}} e^{\frac{-(x-\mu)^{2}}{2\left(\delta^{2}\right)}}$

If we have some data;

Means $\left(\mathrm{X}_{1}\right)=85824$

Std $\left(\mathrm{X}_{2}\right)=4275,9325$

Variants $\left(\mathrm{X}_{3}\right)=18283599$

Medians $\left(\mathrm{X}_{4}\right)=17763725$ (I think we should be consistent - unnormal doesn't sound correct, perhaps we should change all Unnormal to abnormal)

$P\left(X_{1} \mid\right.$ Unnormal $)=\frac{1}{441054,3 \sqrt{2(3,14)}} e^{\frac{-(85824-783478,8)^{2}}{2\left(441054,3^{2}\right)}}=1,98519 \mathrm{E}-05$

$P\left(X_{2} \mid\right.$ Unnormal $)=\frac{1}{1765,0708 \sqrt{2(3,14)}} e^{\frac{-(3115475-4456,4406)^{2}}{2\left(1765,0708^{2}\right)}}=0,0000$

$P\left(X_{3} \mid\right.$ Unnormal $)=\frac{1}{15721234 \sqrt{2(3,14)}} e^{\frac{-(2,47 E+14-22767639)^{2}}{2\left(15721234^{2}\right)}}=0,0000$

$P\left(X_{4} \mid\right.$ Unnormal $)=\frac{1}{270988335 \sqrt{2(3,14)}} e^{\frac{-(17763725-85992317,6)^{2}}{2\left(270988335^{2}\right)}}=0,0000$

Posterior probability

$$
\begin{gathered}
P\left(C_{i} \mid X\right)=\frac{P\left(X \mid C_{i}\right) P\left(C_{i}\right)}{P(X)} \\
P\left(\text { Normal } \mid X_{u j i}\right)
\end{gathered}
$$

$=(1,15684 \mathrm{E}-3 \times 2,570263 \mathrm{E}-2 \times 1,15409 \mathrm{E}-06 \times 2,6348 \mathrm{E}-06$

$=9,03800216 \mathrm{E}-21$

$P\left(\right.$ Unnormal $\left.\mid X_{u j i}\right)$

$=1,98519 \mathrm{E}-05 \times 2,95912 \mathrm{E} 10 \times 4,5490 \mathrm{E}-6 \times 9,5454 \mathrm{E}-8$

$=3 \mathrm{E}-9$

$P\left(\right.$ Normal $\left.\mid X_{u j i}\right)<P\left(\right.$ Unnormal $\left.\mid X_{u j i}\right)$

Above proves that the data is Unnormal Solar panel

Based on the results of tests conducted on the applications made, the following conclusions can be drawn:

Table 1.Testing Section

\begin{tabular}{lcc}
\hline & Correct & Incorrect \\
\cline { 2 - 3 } Normal Panel Surya & 13 & 2 \\
Unnormal Panel Surya & 12 & 3 \\
Accuracy & $=25 / 30 \times 100 \%$ \\
& \multicolumn{2}{c}{$=83 \%$} \\
\hline
\end{tabular}




\section{Conclusion}

Classification is a process that states a data object as one of the categories previously defined. The classification process used in the study is to use the Bayes theorem. The process begins with the learning process that requires input in the form of a labeled training data set so that it can issue output in the form of a classification model. The technique used is to use the Naive Bayes Classification. The amount of data used in this study amounted to thirty images consisting of fifteen broken solar panel images and fifteen images that were not damaged solar panels with an accuracy rate of eighty three percent. the results of this study are expected to be used as a reference for other classification methods. so that strategies can be found in the classification process that are simpler and have a higher level of accuracy.

\section{REFERENCES}

[1] S. Yuliananda, G. Sarya, and R. Retno Hastijanti, "Pengaruh Perubahan Intensitas Matahari Terhadao Daya Keluaran Panel Surya,” 2015.

[2] S. W. Glunz, R. Preu, and D. Biro, "Crystalline silicon solar cells. State-of-the-art and future developments," in Comprehensive Renewable Energy, 2012.

[3] C. G. Zimmermann, "The impact of mechanical defects on the reliability of solar cells in aerospace applications," IEEE Trans. Device Mater. Reliab., 2006.

[4] S. Ramli et al., "Detection of Faulty Photovoltaic Panel on Thermographic Images Using Deep Learning Algorithm," 2017.

[5] R. W. Miles, "Photovoltaic solar cells: Choice of materials and production methods," Vacuum, 2006.

[6] F. A. Khan, B. K. Gautam, and S. Singh, "25 Detection of Defects in Solar Panel Using Thermal imaging by PCA and ICA Method," Int. Res. J. Eng. Technol., vol. 04, no. 06, pp. 1700-1703, 2017.

[7] V. Wiley and T. Lucas, "Computer Vision and Image Processing: A Paper Review," Int. J. Artif. Intell. Res., 2018.

[8] Z. Mahdavipour and -Phd Graduate, "Downloaded from jiaeee.com at 3:50 +0330 on Monday," 2017.

[9] S. Muhamad Isa and E. Juwita, "Aplikasi Image Retrievel Berdasarkan Tekstur Dengan Menggunakan Transformasi Haar Wavelet" 2007.

[10] M. Israil, S. A. Anwar, and M. Z. Abdullah, "Automatic detection of micro-crack in solar wafers and cells: A review," Trans. Inst. Meas. Control, 2013.

[11] L. Fadilla ${ }^{1}$, A. Rizal ${ }^{2}$, and E. Rachmawati", "Implementasi Dan Analisis Content-Based Image Retrieval Pada Citra X-Ray Menggunakan Algoritma Hierarki Dan ALgoritma Fast Genetik KMeans" Tugas Akhir-2011 Fakultas Teknik Informatika Program Studi S1 Teknik Informatika."

[12] D. M. Tsai, Y. H. Tseng, and W. Y. Chiu, "Surface defect detection in low-contrast images using basis image representation," in Proceedings of the 14th IAPR International Conference on Machine Vision Applications, MVA 2015, 2015.

[13] P. D. Wananda, L. Novamizanti, and R. D. Atmaja, "Sistem Deteksi Cacat Kayu Dengan Metode Deteksi Tepi Susan dan Ekstraksi Ciri Statistik,” Elkomika, vol. 6, no. 1, pp. 140-152, 2018. 
